\title{
8. Conducting and Securing Elections in a High-Risk Setting: The Koroba- Lake Kopiago Experience
}

\author{
Chris Kenny and Nicole Haley
}

This chapter offers a security perspective on the elections in Koroba-Lake Kopiago Open electorate during the 2007 general election. It looks specifically at the challenges of conducting and securing elections in a volatile high-risk setting. It finds that the 2007 election was considerably less violent than recent general elections and this was attributable in no small part to the huge investment in security. It also finds that there is considerable room for improvement with respect to inter-agency coordination and electoral administration, and that the role of the security forces should be clarified and pre-deployment training provided to all security personnel prior to the 2012 elections.

\section{Background}

Koroba-Lake Kopiago is a large electorate comprising four rural local-level governments (LLGs). It is situated in the far north-western corner of Southern Highlands Province (SHP), and is one of eight open electorates in the province. There is very little by the way of government service delivery and armed conflict is commonplace, as are illegal weapons (see Haley and Muggah 2006). Indeed the district is awash with weapons. Despite this there are only six regular Royal Papua New Guinea Constabulary (RPNGC) police stationed in the district (all at Koroba Station) and no properly functioning village courts. Political leaders (including many of the ward councillors) spend little time in the district and vast majority of public servants are also absent. It is politicians and candidates who are largely responsible for the proliferation of small arms in the electorate.

In the decade or so leading up to 2007, elections in Koroba-Lake Kopiago had become increasingly violent, so much so that that the elections had failed in 2002 due to widespread violence and electoral malpractice on a scale never before seen in Papua New Guinea elections. Dozens of people (including police) were killed; a high-profile candidate was kidnapped and held for ransom; all airstrips in the western end of the province were closed following threats that planes would be shot out of the sky, and people throughout the province were threatened and intimidated by wealthy candidates and their supporters, often armed with high-powered weapons (Haley 2004). The failure of the 2002 election 
saw the national government assume authority in the province and the greater part of the province's population were without political representation for some 10 months, until supplementary elections were held in April/May 2003.

Post 2002, elections in SHP have been secured by huge investments in security. The 2003 supplementary elections, for example were conducted under a national call-out with the assistance of 2000 additional police, soldiers and prison warders; the 2006 Koroba-Lake Kopiago by-election involved over 800 police and Defence Force personnel, and the 2007 general election in SHP involved both the special police operations (SPO) security force, consisting of 200 regular police and 150 Papua New Guinea Defence Force (PNGDF) personnel, and 2500 additional national elections (NATEL) security personnel.

In the months leading up to the 2007 elections SHP had been subject to a state of emergency (SOE) from August 2006 to February 2007 and thereafter SPO which remained in force until 14 August 2007, by which time the 2007 election had been completed. When announcing the SOE, which was subsequently declared to be unconstitutional, Prime Minister Sir Michael Somare advised that the executive government had taken this step as part of its ongoing efforts 'to restore governance, security and public administration in the province' and in an effort to 'avoid at all costs a repetition of the events of 2002 where the national elections were declared illegal due to the use of arms by competing parties'.

The SOE was accompanied by a gun amnesty, which had very limited success. Only a handful of the estimated 2500 factory-made weapons thought to be in civilian hands in SHP (Alpers 2005) were recovered and less than 300 firearms in total. Like past weapons collection initiatives it yielded mainly home-made weapons (see Chapter 6). In reality the SOE and SPO had little impact in KorobaLake Kopiago. This was because none of the SOE troops were stationed in the electorate, being deployed instead to the major urban centres and key locales on the Highlands Highway and major trunk roads. In the case of Koroba-Lake Kopiago, much of the electorate is accessible only by road.

\section{NATEL 07}

In contrast to the SOE/SPO, a PNGDF platoon was deployed to Koroba District during the national elections security operations, NATEL 07. Lieutenant Chris Kenny commanded the security operations in the electorate. That troops were deployed to Koroba-Lake Kopiago as part of the national elections security operations was hardly surprising, as the electorate was deemed to be high risk, 
being one of the five open electorates in which the 2002 national elections had failed. What was surprising was that it had not been a focus of the SOE/SPO operations. Taskings under NATEL Ops 07 were to:

- create an environment conducive to good elections

- foster community support

- conduct awareness

- gather intelligence

- identify and contain security threats

- oversee the conduct of polling

- conduct post-election operations.

Given the events of 2002, SHP was assessed as being a likely problem area with respect to the 2007 elections. On this basis the Papua New Guinea Electoral Commission (PNGEC) decided that SHP would poll first and on a single day, 30 June 2007. For the most part, pre-polling operations in the Highlands were focused on SHP, with insertion scheduled for 18-19 June, pre-polling operations 20-29 June, polling 30 June, post-election operations 1-31 July and withdrawal 1 August. The decision to deploy security personnel to SHP well in advance of polling was prudent, particularly in Koroba-Lake Kopiago, given the absence of SOE/SPO operations in the lead-up to the elections.

In terms of threats, we expected to find and have to deal with:

- illegal weapons

- unresolved election-related issues

- candidates and supporters

- criminal elements

- organized syndicates.

Pre-polling operations focused on minimizing these threats. Being deployed two weeks prior to the scheduled commencement of polling meant we were in a position to undertake detailed reconnaissance and attend to security threats well in advance of polling. It also enabled the security forces to make informed decisions about where best to deploy our limited security resources on polling day. Importantly, the pre-deployment of security personnel meant we were also able to undertake election and security related awareness, and this contributed to the good security situation observed on polling day (see Figure 8.1). Unfortunately, however, the security personnel were not well supported during this period, having limited rations, poor communication, and a shortage of vehicles and fuel. 


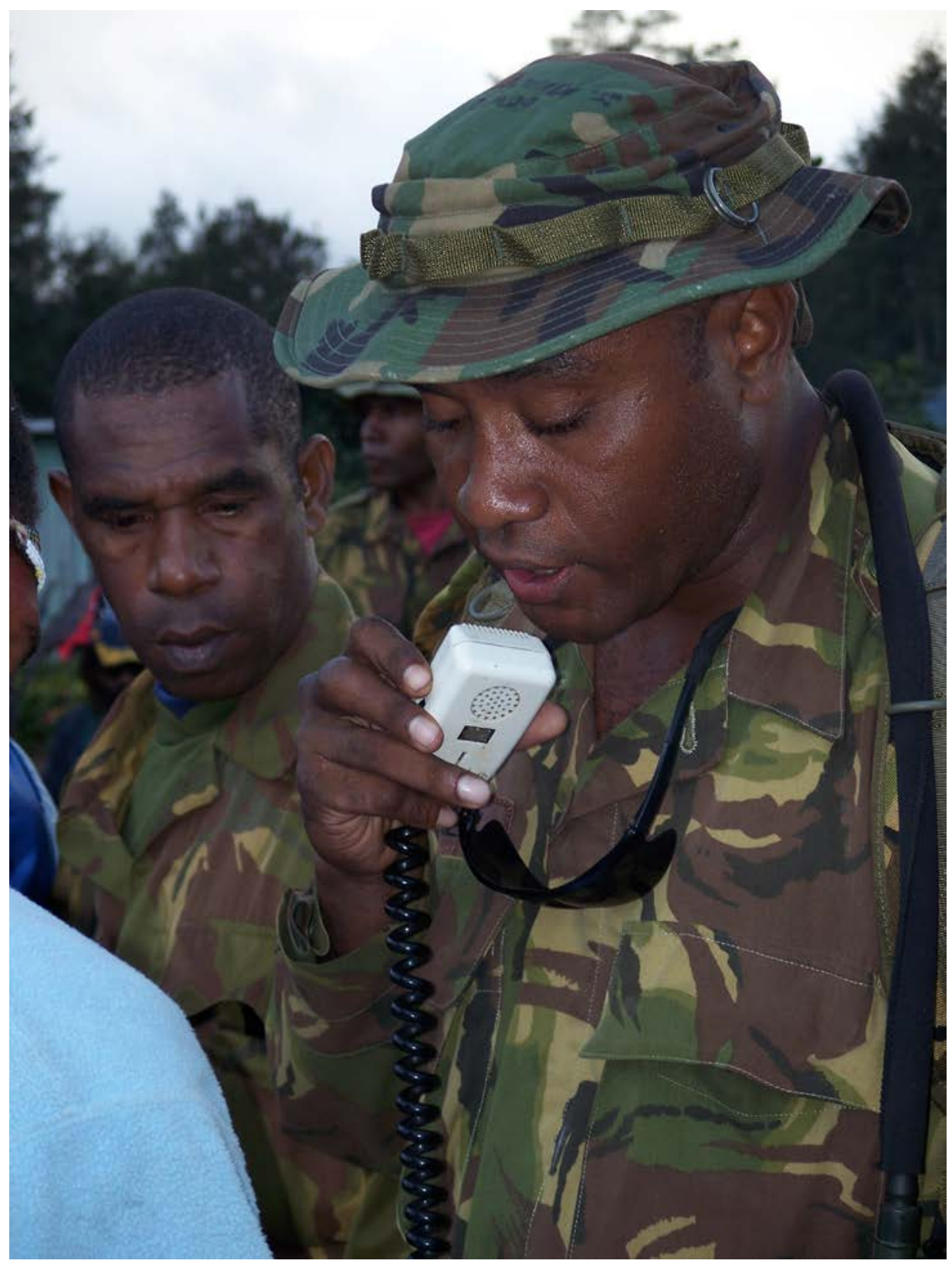

\section{Figure 8.1: Lieutenant Kenny leading awareness at Koroba}

What the security personnel had not expected to encounter were chaotic preparations on the part of the PNGEC. Nor did we expect that we would effectively have to conduct the elections. Certainly we were not trained to run the elections and in fact, unlike the police, did not receive election-related pre-deployment training. Instead we were merely issued with a little security booklet (RPNGC 2007a), with which we were expected to familiarize ourselves. 
Much of the NATEL 07 PNGDF contingent, who as it turned out were given special police powers and deployed to the most high-risk settings, were unclear about their role in general, and about electoral processes and electoral offences more specifically.

Another thing we did not expect to encounter were international and domestic observers. The security booklet we were issued with did not include anything about the domestic observation. An updated version of the booklet, Election Handbook 2007 (RPNGC 2007b), printed in June 2007, did include a section of observers but was unfortunately issued too late and as a consequence could not be distributed to security personnel already in the field.

\section{Election preparedness}

It will, of course, always be difficult to conduct elections in remote rural electorates that lack basic infrastructure and are accessible for the most part only by air, but that said the planning, organization, administration and preparedness for the elections in Koroba-Lake Kopiago was woefully inadequate. Logistics, administration and planning were hampered by the fact that the key electoral officials, namely the returning officer, Denny Hongai, and assistant returning officers, Don Piru and Haddick Sakopa, were absent much of the timeespecially in the lead-up to polling. For instance, when the security personnel arrived in the electorate the returning officer was absent. He was reportedly in Mendi, the provincial headquarters, collecting his election materials. He arrived in the electorate, with his electoral supplies, approximately 36 hours ahead of the commencement of polling, claiming to have been delayed in Mendi waiting for pre-polling allowances and materials.

Communications proved extremely problematic throughout the election period for both the election officials and the security personnel. A lack of radios and failure of the joint communications strategy meant that there was no communication between the election manager, returning officer and assistant returning officers once in the electorate and that it was difficult for those in the field to get accurate information about the movement of air transport. For much of the election period the returning officer had no idea what was going on outside his immediate purview. And his purview was limited indeed, as he choose to remain safely ensconced within the security of the Koroba hospital grounds where the security operations were based. The assistant returning officers for North Koroba and South Koroba LLG areas likewise chose to base themselves within the secured hospital compound and they proved as ineffectual as the returning officer.

Communications for security forces were not ideal either, in that mobile phones, which worked and upon which we relied in other parts of the Highlands, did 
not work anywhere in Koroba-Lake Kopiago electorate. The PNGDF-issued radio also proved problematic. It enabled radio contact with headquarters in Port Moresby but could not be used to contact senior officers at the provincial headquarters in Mendi. Likewise, it did not permit contact with the police who were commanding the security operations in the province, who were operating on a separate radio system. Fortunately the domestic observers had a satellite phone and made it available to both the security and electoral personnel. Even with the phone, it proved impossible to contact the SHP election manager, and so desperate pleas for ballot box seals (see below) and later for air transport to insert polling teams into polling places that were accessible only by air, had to be relayed directly to the electoral commissioner and operations manager via advisers attached to the Electoral Support Program in Port Moresby.

The day before polling was due to commence the security personnel and observers gathered in the hospital grounds to witness the distribution of ballot papers and election materials. Neither the returning officer nor assistant returning officers were interested in undertaking this important task, the latter being more interested in finalizing the lists of polling officials, which seemingly involved meeting with delegations representing key candidates and an endless stream of would-be election officials. As the day progressed several thousand people gathered outside the hospital fence, wanting to know the composition of polling teams, and who was to be engaged to conduct the elections.

Around mid-morning it became evident that the key electoral officials, namely the returning officer and the assistant returning officers for North and South Koroba, were unwilling or unable to make the necessary election preparations. It was also evident to observers and security personnel that the returning officer and assistant returning officers were supporting different candidates, which was detrimentally impacting upon their performance. Accordingly security personnel, under the eye of the domestic observers, stepped in and sorted and distributed all the essential election supplies such as the ward rolls, pens, rulers, candidate posters, ballot papers and T-shirts.

One of the most critical aspects of the election preparations took place without the active involvement of the election officials, namely the distribution of ballot papers. This was done by Lieutenant Kenny and his section commanders, with guidance from the domestic observers who advised that the number of papers issued to each ward should match the enrolments in that ward and that each ward should be allocated only five additional papers. The observers and the security commander (but no electoral officials) kept a register of papers issued to each polling station. Several of the candidates subsequently became aware of this and wrote to the returning officer on 7 July 2007 seeking clarification about the total number of ballot papers issued to each polling place. In the same letter they also alleged that unnamed candidates had printed extra ballot papers. 


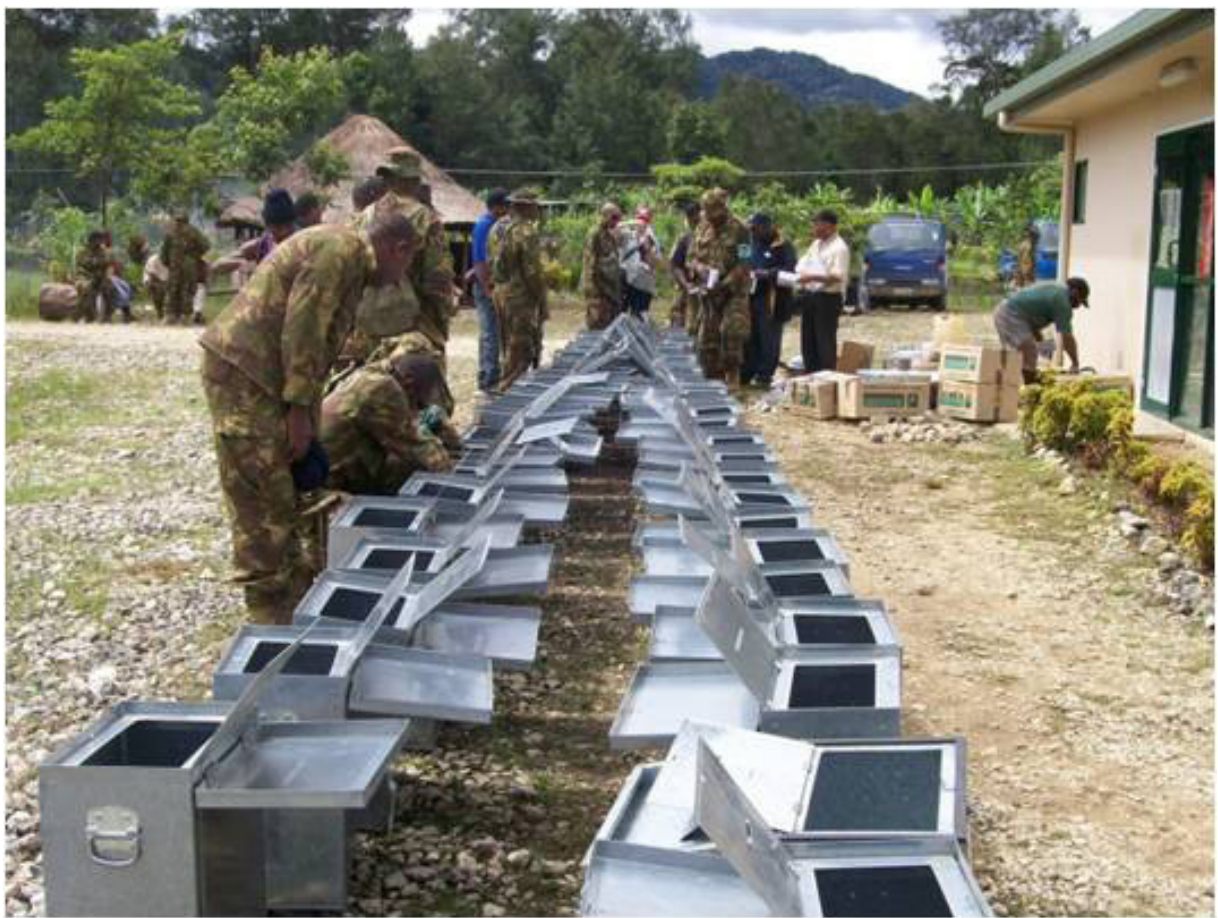

Figure 8.2: Papua New Guinea Defence Force distributing election materials

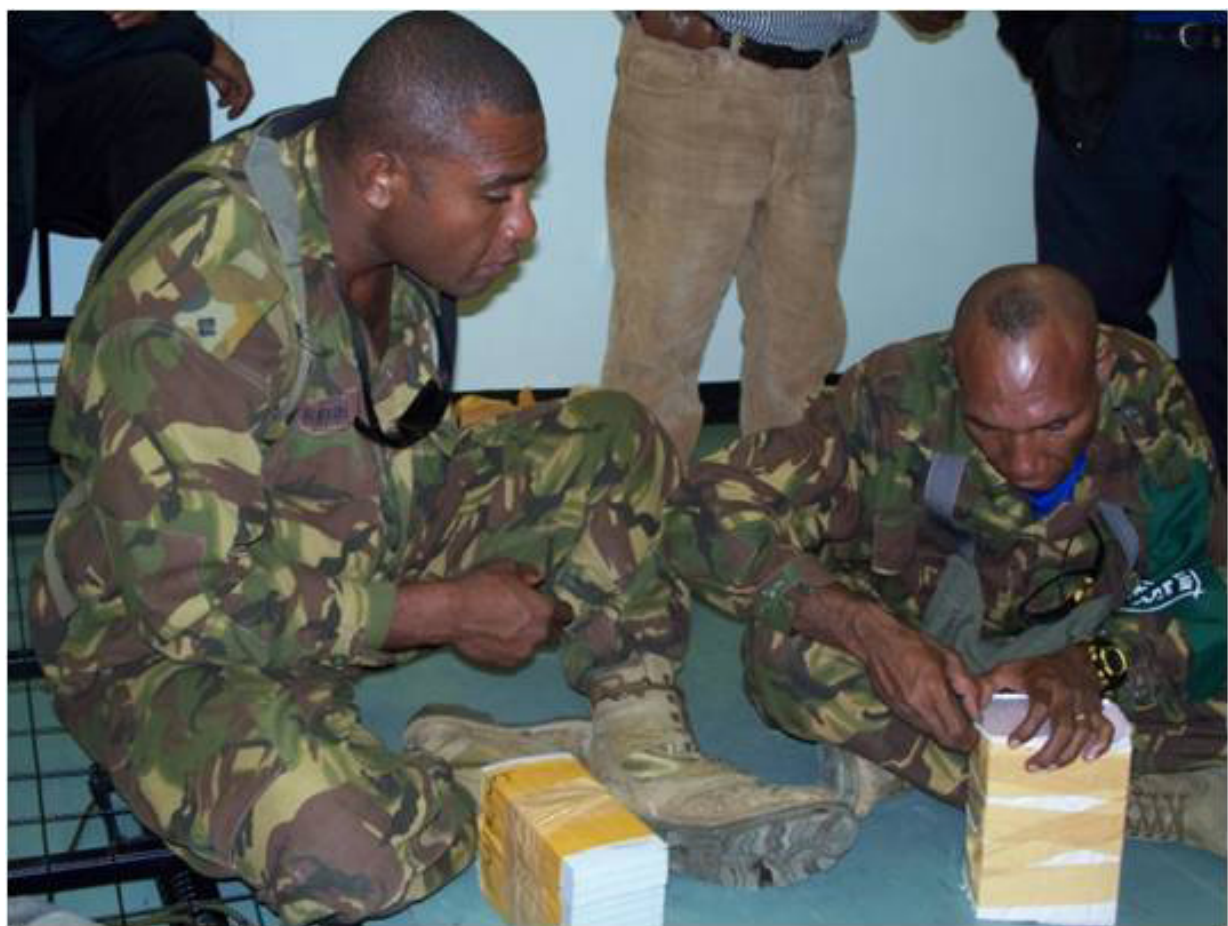

Figure 8.3: Lieutenant Kenny distributing ballot papers 
As the day progressed it became evident that the returning officer had given no real thought to the logistics of inserting the 51 polling teams he was responsible for. He reported that he had not received his pre-polling advance and so was not in a position to hire vehicles and/or purchase fuel. Key operational and logistical matters had been left to the last minute, and were dependent on the availability of funds. In the absence of these, the returning officer appeared completely paralysed. He spent much of the day before polling trying to make contact with the election manager and SHP finance officer seeking to enquire about his pre-polling funds, instead of undertaking the final election preparations. In his stead the PNGDF arranged for and funded the insertion and extraction of polling teams. They achieved this by using PNGDF vehicles and fuel and by commandeering local vehicles and or local fuel supplies for use during the election. Without this action the election would not have proceeded.

Similar observations were made in Kagua-Erave Open electorate where the security forces were likewise relied upon to transport ballot boxes and polling teams because funds that should have been released prior to polling were not received until after the polling was complete (see Chapter 20). The pre-polling advance the returning officer had been expecting was meant to cover prepolling expenses, including the purchase of fuel to insert polling teams, hiring of drivers and security, polling team advances, and incidental allowances for polling officials. It was not received until two days after the commencement of polling and then the amount received was less than half of what had been expected. When the funds arrived, the returning officer requested that both authors witness and record the counting of the money, reporting that in the past he had received less that the full amount indicated on the paperwork he was expected to sign. In this instance, the paperwork accompanying the 'advance' indicated that K99,869 should have been received, although we confirmed that only K43,500 was received. Similar observations were made by the Nicole Haley during the 2006 Koroba-Lake Kopiago by-election, where official paperwork indicated that payments had been made to phantom polling officials. While we understand that delays in the release of funds, in this case, were in part due to the late appropriation from Treasury, this does not explain the missing money.

In Koroba the lists of polling officials were finalized at dusk $(5.45 \mathrm{pm})$ on the eve of polling and were still being read out and argued over as night fell (see Figure 8.2). Polling teams were instructed to return at first light on polling day for training. In the end, only presiding officers were offered training and this was very cursory, lasting only 20 minutes with no opportunity for questions. The training was cut short when polling officials tried to ask about their polling allowances and raised complaints about outstanding payments dating back to the 2003 supplementary elections and the 2006 Koroba-Lake Kopiago by-election. At Kopiago, polling officials received no training. Throughout the electorate polling officials were critical of this lack of training. Training manuals were not used during the training session at Koroba and were not issued to polling officials anywhere in the Koroba-Lake Kopiago electorate. 


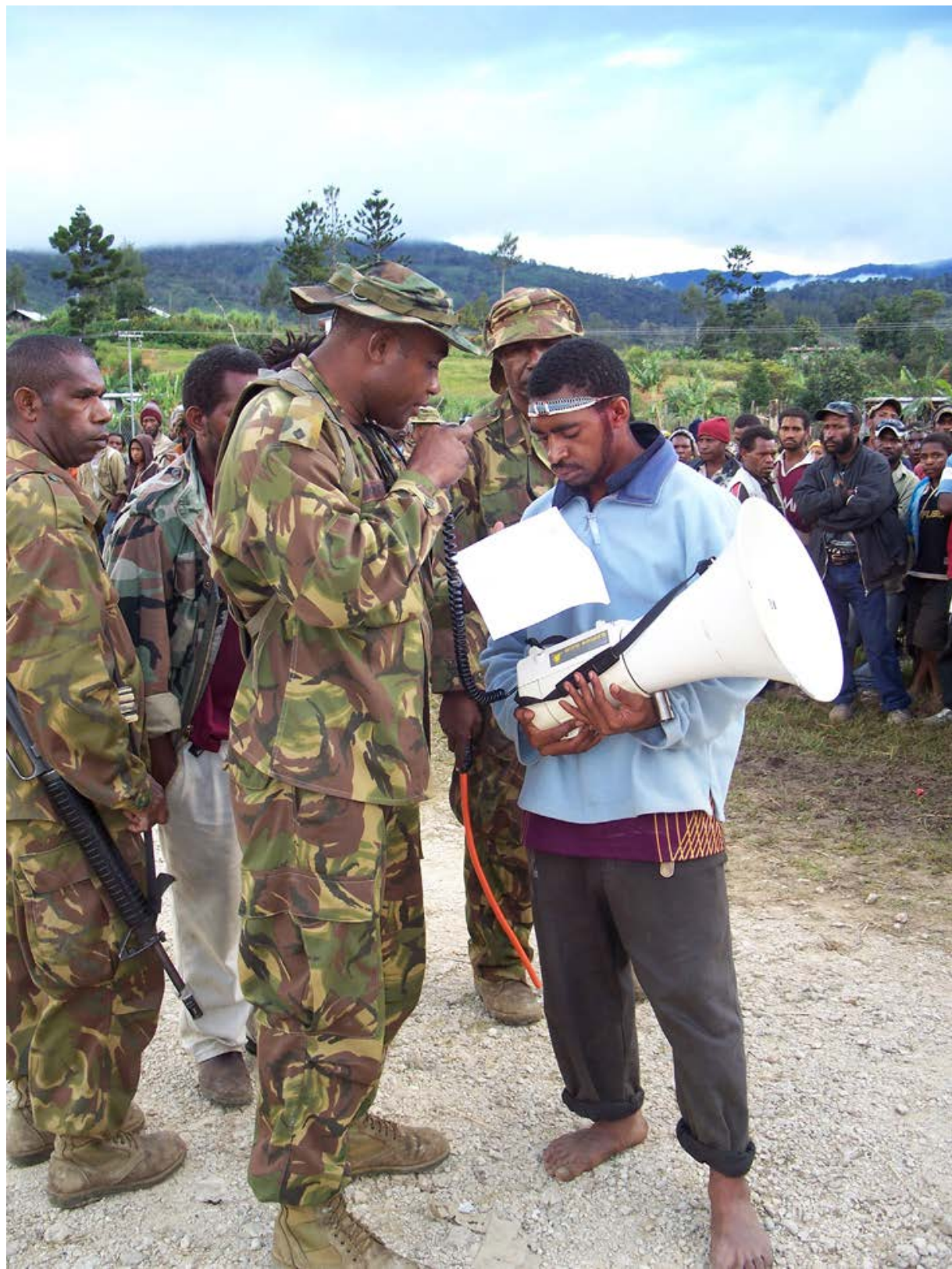

Figure 8.4: Lieutenant Kenny reading out polling officials' names

Around $3.30 \mathrm{pm}$ on the eve of polling an additional 60 unarmed police arrived to supplement the 31 Defence Force personnel deployed to oversee the elections in Koroba-Lake Kopiago electorate. Collectively we were expected to secure 51 polling stations against a potentially well-armed populous in an electorate where the 2002 general elections had failed. By way of comparison, the 2006 
Koroba-Lake Kopiago by-election, which had taken place some 11 months earlier in July 2006, had involved a security force of over 800 police and Defence Force personnel.

Knowing the history of the electorate, specifically that a police officer had been killed at Koroba during the 2002 elections and that there had been further election-related deaths in the lead-up to the 2007 elections, several of the unarmed police refused to be deployed with polling teams. They were redeployed to Enga Province before polling was complete in SHP.

\section{Polling}

In SHP, where polling commenced, the provincial police contingent was boosted by 2500 additional NATEL security personnel (2000 police - mostly auxiliary and community police - and 500 PNGDF personnel). Despite the large security presence, security remained thin on the ground. Typically one or two unarmed police provided the security at most polling stations, while armed PNGDF provided security at more high-risk locations and acted as response units. That said, we are aware of several wards where polling proceeded in the absence of polling security. The Yatemali polling station is a case in point (see below).

One-day polling, scheduled for 30 June, proved unworkable in Koroba-Lake Kopiago due to poor planning and infrastructure, the late release of funds, and a lack of vehicles and air transport. Polling was delayed by up to two days in those areas where polling teams needed to be inserted by air. In total it took five days to complete the polling.

In terms of the conduct of polling, voting irregularities were the norm rather than the exception in Koroba-Lake Kopiago. Security personnel and observers alike witnessed rampant cheating and malpractice, including underage voting, multiple voting, 'line-up' voting, and serial voting. There was no secret ballot and excess ballot papers were used at many polling stations. Assisted voting, much of it seemingly forced, was commonplace and at several polling stations polling officials were observed to be issuing pre-marked ballot papers. At other polling stations groups of young men were issued with entire books of ballot papers, which they were observed to be complete en masse (Figure 8.5).

In two cases where pre-marked ballot papers were being issued by polling officials and candidate scrutineers, security personnel stepped in and insisted that the polling station be closed down mid-afternoon. The presiding officers from both polling stations, namely Ereiba 1 and Ereiba 2, subsequently complained to the assistant returning officer and to domestic observers, including Nicole Haley, insisting that voting had been 'going well', that 'people were voting for the 
candidate of their choice' and that the 'votes were being shared by all of the candidates'. They subsequently wrote to the returning officer requesting that polling be resumed on 1 July 2007. The request was denied. As it turned out, over 80 percent of first preference votes in these two boxes went to the former MP, Herowa Agiwa.

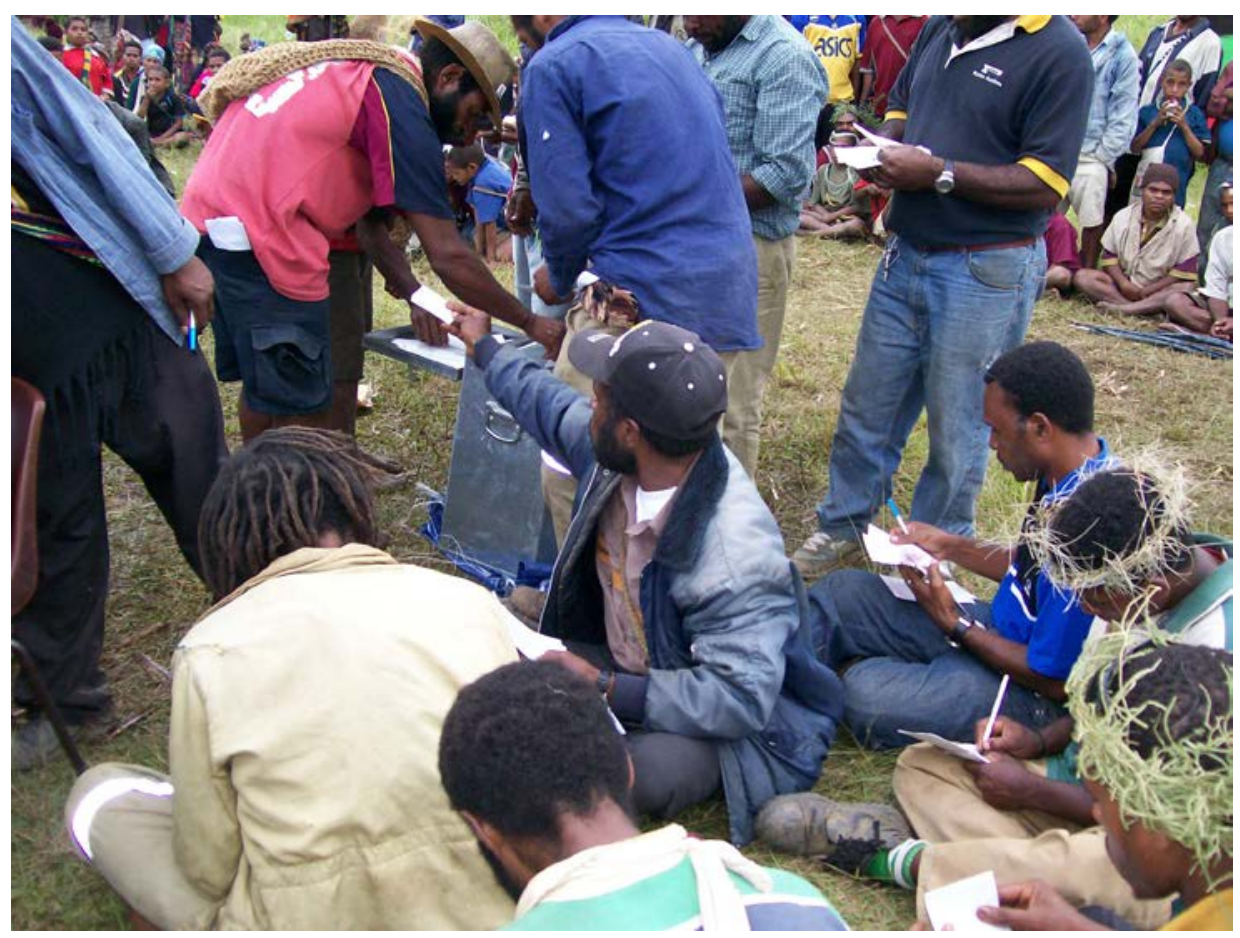

Figure 8.5: Block voting at Tumbite, 30 June 2007

The location and positioning of polling stations clearly contributed to and facilitated the widespread malpractice observed. For example, there were seven polling places at Koroba Station (Teria 1, Teria 2, Pandu, Andiria 1, Andiria 2, Koroba Station and Kereneba Part 2). These were all set up within five minutes walk of each other, and voters were observed moving backwards and forwards between them. Three of these polling stations were moved, the returning officer explained, from their gazetted locations to 'make it easier for voters to move between polling stations'. At Pureni, in South Koroba LLG area, four polling stations (Tumbite, Pubulumu 1, Pubulumu 2 and Tangimapu) were set up on Tumbite airstrip. Three of the four polling stations had been moved from their gazetted locations on grounds of alleged security threats, although it should be noted that no such threats were reported to the security personnel. It is also worth noting that this is one of the locations where the most blatant fraud was observed, in that a group of approximately 30 young men sitting at desks and in small groups under tarpaulins completed close to 6000 ballot papers in 
the space of six hours. Tumbite and Pubulumu are also two of the key areas in which enrolments in already over-enrolled wards increased further during the verification stage, so much so that at the time of the 2007 election enrolments were three to four times greater than they should have been (see Chapter 21).

In the immediate post-polling period, security personnel who had witnessed such irregularities reported confusion about the true nature of their role. They questioned whether they were there merely to secure the election process as tainted as it was, or whether they should have done more to prevent or deter voting irregularities, and whether they should have shut down the polling stations. Their questions evidenced the fact that they lacked a clear understanding of proper electoral practice and electoral offences more specifically, and that predeployment training needs to be more comprehensive. Some were clearly of the opinion that the law was being broken and that electoral offences were being committed but they remained unsure about their powers to intervene. Their uncertainty was compounded by the fact they were never officially sworn in.

\section{Post-polling operations}

Past elections in Koroba-Lake Kopiago have seen ballot boxes hijacked at the close of polling. A key task for the security personnel on polling day was the safe transportation of ballot boxes back to secure distribution points. In this case, all boxes were safely returned to Koroba, although there was at least one well planned attempt to intercept some of the North Koroba ballot boxes. It was successfully thwarted by Lieutenant Kenny. The attempted ruse involved a fake mobile squad vehicle, and supporters of an SHP regional candidate dressed in mobile squad uniforms attempting to 'collect' ballot boxes at the close of polling. The same group was later reported to have made concerted attempts to intercept ballot boxes in Tari-Pori electorate as well, and somewhat incredibly was observed to fire upon the crowd gathered outside the Tari police station (see Chapter 20).

As polling teams returned to Koroba at the close of polling, it was evident that many of the presiding officers were incapable of completing their returns due to poor literacy and numeracy. Without exception returns and polling day paperwork were completed after the fact over several days. Many presiding officers sought and requested assistance from the security personnel and observers when completing their returns. They did so because the returning officer had failed to keep a record of ballot papers issued, or a register of unused ballot papers. Few presiding officers knew how many ballot papers they had been issued with. As presiding officers completed their returns, many 'found' books of completed ballot papers that had not been cast on polling day. Some 
went as far as to assert that boxes which had been sealed in the presence of observers and security personnel at the close of polling had in fact been sealed prematurely and that the boxes (which were sealed only with padlocks) should be reopened to allow the additional papers to be inserted.

One such case, was that of Yatemali, where the presiding officer lost control of the polling station, including the ballot box and papers, after a fight broke out. The box was taken off into the bush by candidate supporters but was subsequently returned when a PNGDF rapid response unit turned up. The ballot box was returned with 212 completed ballot papers inside. Security personnel also demanded the return of the remaining 685 ballot papers issued to that polling station. Initially these were not forthcoming and on this basis the presiding officer requested fresh polling on 1 July 2007. In his written request he alleged that the returning officer and assistant returning officer had 'deliberately failed to protect the polling' by 'failing to provide essential security'. The request for fresh polling was denied. In the face of this, the missing papers were returned to the presiding officer the following day, with the instruction that they 'must be counted'. The papers were evidently returned completed. Both the presiding officer and returning officer were quite insistent that the security personnel should open the ballot box so that the returned ballots might be counted. They claimed that they had both received death threats and that their lives were in danger if the ballots were not allowed. Security personnel refused to open the box, and although it was transported to Mendi for counting, the box was set aside and not counted.

The delayed release of pre-polling funds, coupled with the funding shortfall detailed above resulted in reduced payments to polling officials, which in turn gave rise to much discontent and saw the majority of returning officers withhold their returns and refuse to attend the count. It also saw polling officials, candidates, and their supporters initially block the transport of ballot boxes to Tari. A full day's mediation on the part of the security personnel was needed in order to gain community consent to transport the ballot boxes to the counting centre. Once consent had been gained the ballot boxes were transported to Tari under security escort without incident. The boxes, along with those from the rest of Hela region, were held in Tari, at the Tari police station, while the Huli candidates argued with the electoral commission over the location of the count. The Hela people had wanted 'their boxes' counted in Tari and not in the provincial headquarters where counting for the entire province was centralized. As a demonstration of their resolve they blockaded the Tari police station where the ballot boxes were being held. As a result, the transportation of the boxes to the counting centre in Mendi was delayed by 10 days.

The observers and security personnel who had overseen the transportation of the ballot boxes to Tari spent several days in Tari waiting for a decision on the 
counting venue. This was completely unexpected and presented huge logistical difficulties in that all the local guest-houses were fully booked and being used by the electoral staff and security personnel who were deployed to Tari for the elections. Eventually the observers managed to secure the use of a threebedroom Evangelical Church of Papua New Guinea mission house at Halenguali. It was subsequently used to lodge the 31 PNGDF security personnel who had been stationed at Koroba and 10 domestic observers.

Accommodation was not the only difficulty faced. Extended delays in both Koroba and Tari meant that the security personnel had exhausted their rations and allowances. Thankfully, the Porgera Joint Venture community affairs staff, based in Tari, assisted by providing additional rations. They later assisted with fuel as well, when the NATEL forces who had been based in Koroba-Lake Kopiago were redeployed to Enga Province. Indeed, fuel became a real issue when George Tagobe, a candidate for Tari-Pori Open electorate and the operator of Hela Fuel Distributors, the sole commercial fuel distributor in town, refused to sell fuel to the PNGDF and observer team claiming outstanding debts against both the PNGDF and PNGEC dating back to the 2006 Koroba-Lake Kopiago byelection and the SOE operations. ${ }^{1}$

From Tari, the PNGDF platoon that had been based at Koroba-Lake Kopiago was redeployed to Wabag as part of the 1020-strong NATEL security force that oversaw polling and counting in Enga Province. They remained in Wabag after the polling, to secure the count and to respond to post-election violence, but were subsequently deployed back to SHP to respond to post-election fighting in Kagua-Erave electorate.

\section{Conclusions}

This chapter has explored the challenges of conducting and securing elections in a high-risk setting. It has highlighted a raft of administrative deficiencies in respect of administration and planning on the part of the PNGEC. It has also identified aspects of the security operations that might be improved. These include more comprehensive pre-deployment training for PNGDF personnel, and improved communications so that there is secure reliable communication between all key stakeholders. The chapter finds that security in the Highlands

\footnotetext{
1 A fortnight or so before the issue of writs, Alphonse (2007) had reported that there were likely to be disruptions to the elections due to the 'non-payment of outstanding monies for services and goods provided during the state of emergency operations'. He specifically warned that Hela Fuel Distributors managing director, George Tagobe, was refusing to supply fuel to both security personnel and electoral commission staff on account of K100,000 in outstanding invoices.
} 
during the election period was much improved, and that a factor which contributed to the good security situation was the pre-deployment of NATEL forces a full two weeks prior to polling.

Over the course of the election period, the security personnel worked very long hours, with little rest. Throughout the country they were observed to be better behaved than in past elections and to have conducted themselves professionally in the main (Haley and Anere 2009:47). They were observed to use mediation and community policing to quell disputes and diffuse potentially volatile situations and were rarely seen to exercise any unnecessary force. Although it was not their role, they also stepped in to ensure the smooth running of the elections, contributing to both awareness and logistics. Indeed in several places the security forces not only contained potentially volatile situations, but effectively ran the elections (see Chapters 7, 20 and 21). Were it not for their intervention it is likely the elections would have again failed.

Although they performed well overall and made a significant contribution to the conduct of elections, the security personnel found it difficult to deter voting irregularities. This was possibly due to the fact that many were unarmed and most poorly trained. Those in the PNGDF contingent deployed to Koroba-Lake Kopiago Open electorate reported that they had received no pre-deployment training. As a consequence many seemed unclear about their role in general, and about electoral processes and electoral offences more specifically. Clearly, the role of the security forces needs to be clarified and pre-deployment training provided to all security personnel prior to the 2012 elections, so that they are not seen to be securing a process tainted by fraud, malpractice and significant irregularities (cf. Institute of Policy Studies 2004:26) and so that they might make a significant contribution to electoral governance. This is particularly important given the role the security forces play at election time and the fact that elections are now a whole-of-government exercise. Clearly the RPNGC, PNGDF and Correctional Services personnel deployed during elections need specific and consistent, as opposed to ad hoc, training on electoral procedures and electoral offences, guidance on when to intervene, and the extent of their special constable powers under a national call-out. Finally we recommend that electoral officials and security personnel charged with the responsibility to run and secure elections in known trouble spots and high-risk settings be better supported. Left to their own devices without effective communication or adequate funding they are deeply compromised. 


\section{References}

Alpers, P., 2005. Gun-running in Papua New Guinea: From Arrows to Assault Weapons in the Southern Highlands. Geneva: Small Arms Survey.

Alphonse, A., 2007. 'Elections likely to be disrupted', The National, 16 April 2007.

Haley, N., 2004. 'A failed election: the case of the Koroba-Lake Kopiago Open electorate', in P. Gibbs, N. Haley and A. McLeod, Politicking and Voting in the Highlands: The 2002 Papua New Guinea National Elections, SSGM Discussion Paper 2004/1. Canberra: State, Society and Governance in Melanesia Project, The Australian National University, pp. 16-26.

Haley, N. and Muggah, R., 2006. 'Jumping the gun: armed violence in Papua New Guinea', in Small Arms Survey 2006: Unfinished Business. Oxford: Oxford University Press, pp. 164-187.

Haley, N. and Anere, R., 2009. The 2007 Papua New Guinea National General Elections: Domestic Observation Report. Special Publication No. 52. Port Moresby: The National Research Institute.

Institute of Policy Studies, Victoria University, New Zealand, Papua New Guinea Institute for National Affairs and Transparency International (PNG), 2004. The Election Audit Report. Election Lessons Prepared for the PNG Electoral Commission on 3 By-elections Held in Papua New Guinea in mid 2004. Wellington: Victoria University.

RPNGC (Royal Papua New Guinea Constabulary), 2007a. Free and Fair 2007 National General Election Duties and Responsibilities of Police Officers. Port Moresby: RPNGC Material Production Unit.

RPNGC (Royal Papua New Guinea Constabulary), 2007b. Election Handbook 2007. Port Moresby: RPNGC Material Production Unit. 